\title{
Usefulness of training camps at high altitude for well-trained adolescents
}

\author{
Jiří Suchý* and Jakub Opočenský \\ Faculty of Physical Education and Sport, Charles University in Prague, Prague, Czech Republic
}

Copyright: () 2015 J. Suchý and J. Opočenský. This is an open access article licensed under the Creative Commons Attribution License (http://creativecommons.org/licenses/by/4.0/).

\begin{abstract}
Objective: Opinions on the suitability of sports training at altitudes of 1800-2200 m above sea level (ASL) for increasing performance in youth are not unanimous. The objective of this study was to test the influence of a ten day altitude training camp on performance in well-trained adolescent cross-country skiers. Methods: A running test of $3 \times 2 \mathrm{~km}$ (aerobic, anaerobic and critical intensity) was used with a rest interval of 10 minutes. The test was performed 4 times - an initial test at a lowland (900 m ASL) prior to departure for altitude, two tests at altitude (1850 m ASL), a final test ten days after returning to lower altitudes. The aerobic, anaerobic and critical load intensities were set by graded a load test. For all individual tests, the participants maintained the same heart rate individually defined for the various segments using a heart rate monitor. Changes in speed between the tests were compared. The body's internal response was also monitored by the concentration of lactate ( 2 and 8 minutes after each exertion). Participants: Well-trained adolescent cross-country skiers $(N=11$, age: $14.4 \pm 1.2$ years, weight: $54.4 \pm 8.6 \mathrm{~kg}$, height: $170 \pm 7 \mathrm{~cm}$, fat: $13 \pm 2.6 \%)$. Results: The average times attained in the first altitude test for aerobic and anaerobic load were higher $(p<.05)$ than in the entry test at low altitude. In the second altitude test the average times for all intensities were significantly $(p<.05)$ higher than in the first altitude test. In the tests after returning to the lower altitudes the times attained for all intensities were on average higher than at altitude. The average lactate concentration levels following the various intensities were similar $(p>.05)$. The dynamics of the cool-down monitored via the lactate value at the eighth minute after completing the relevant segment showed that at altitude the adolescents cooled down significantly $(p<.05)$ slower rate following the aerobic and anaerobic intensity than at low altitude. For critical intensity there was no statistically significant $(p<.05)$ change in the kinetics of cooling down measured by lactate concentration between altitude and the low altitudes. Conclusions: In the model we were testing, the ten day altitude camp was to verify a positive effect on adolescents in acute improvement of their performance ten days after their return to low altitude. Thus it is physiologically suitable for adolescents, as with adults, to include altitude training with the objective of a subsequent rise in performance at low altitude. In accordance with the principles of a long-term approach to sports training corresponding to development, however, we believe that the use of higher altitudes is unnecessary for adolescents.
\end{abstract}

Keywords: adolescent, sport training, high altitude, testing, cross country skiing

\section{Introduction}

The use of lower partial air pressure has long been one of the most frequent legal options for increasing sports performance in adult athletes, primarily for endurance sports. Lower partial air pressure can be induced naturally (through higher altitudes) or artificially (e.g. using special tents or barochambers). The demands of

\footnotetext{
* Address for correspondence: Jiři Suchý, Department of Pedagogy, Psychology and Didactics, Faculty of Physical Education and Sport, Charles University, José Martího 31, 16252 Praha 6 - Veleslavín, Czech Republic. E-mail: email@jirisuchy.cz
}

staying and training at higher altitudes stem from the differing physical and climate conditions compared to low altitudes. Particularly for endurance sports, altitude training is considered one of the basic methodological factors for developing sports performance. The reason why it holds such significance today (despite certain difficulties) is the search for further (legal) ways to increase the effectiveness of training practices commonly applied in at low altitude.

A whole range of studies showing the positive influence of altitude training on physiological and biochemical indicators and improved performance in top adult athletes have been conducted over the past 
fifty years. Meta-analysis of the studies of the influence of high altitudes on the performance of peak athletes over the past thirty years has shown a $5.2 \%$ increase in performance in comparison with the same training at standard altitudes (Bonetti \& Hopkins, 2009). Wilber (2004) and Millet and Schmitt (2012) state that the best thing for peak endurance athletes is permanent residence at an altitude of 1800 to $2300 \mathrm{~m}$ above sea level (ASL). If a permanent move to such an altitude is not possible, then Levine and Stray-Gundersen (1997) and Heinicke, Heinecke, Schmidt, and Wolfarth (2005), for example, consider it optimal to repeat altitude training camps several times over the course of the annual training cycle with a minimum length of 21 days due to the course of acclimatisation. This length is optimal, but due to socioeconomic reasons it is not always possible (Suchý \& Dovalil, 2009). Saunders, Pyne, and Gore (2009) recommend an altitude stay of at least 2 weeks to improve competitive performance at altitude and 3 to 4 weeks to improve performance at low altitude. Shortened ten to twelve day training camps at altitude have been looked at by, for example, Svedenhag, Saltin, Johansson, and Kaijser (1991) and Suchý (2012), Suchý, Pernica, and Opočenský (2014), who studied the influence of such shortened stays on performance and selected physiological and biochemical indicators. These studies confirmed that even 10 to 12 day stays and training at altitude have a positive influence on the monitored indicators.

A number of studies have been published that confirm better performance of adolescents who were born and lived at high altitudes compared to those living at lower altitude (Pollard et al., 2001). There are no data about safe absolute altitudes for ascent in children about 2500 m ASL (Pollard et al., 2001). Pahud (1986) states a tolerance of up to $3000 \mathrm{~m}$ ASL at the age of 14 to 16 years.

Opinions on the usefulness of high-altitude training for increasing performance in adolescents differ. Christoulas (1999) and Christoulas, Karamouzis, and Mandroukas (2011) present positive effects of a 21 day altitude training camp on adolescent cross-country skiers. Son, Kim, Kim, Ohno, and Kim (2012) found a positive influence of a five week stay at $2100 \mathrm{~m}$ ASL and a four-hour training at altitudes of around $2700 \mathrm{~m}$ ASL on endurance indicators in 13 to 17 year old downhill skiers. We did not find any work dealing with the influence of a ten day altitude training camp on performance in adolescents.

Exact identification of the actual load intensity is an important starting point for the management of sports training. The majority of authors follow Wilmore, Costill and Kenney (2008) and Bunc (1990) and use a simplified system of three basic load intensities: aerobic (AP), anaerobic (ANP) and critical (CI). AP is fully covered by aerobic energy - i.e. with oxygen supply and the use of glycogen, later also fats. Standard lactate values at AP level are 0.8 to $2 \mathrm{mmol} \cdot \mathrm{l}^{-1}$ in blood (Keul, Kindermann, \& Simon, 1978). ANP expresses the highest intensity of constant load, and aerobic processes are insufficient to meet the energy demand. Neumann, Pfützner, and Berbalk (1998) state a standard ANP value of around $4 \mathrm{mmol} \cdot \mathrm{l}^{-1}$ in the blood. CI is generally defined as the maximum consumption of oxygen in the muscles. Further increase of intensity beyond CI no longer leads to a greater consumption. CI standard values of lactate concentration for: 5 to $7 \mathrm{mmol} \cdot \mathrm{l}^{-1}$, depending on the somatotype, proportion of muscle tissue, sport specialisation and individual level of training (Keul, Kindermann, \& Simon, 1978).

\section{Objectives}

The objective of the study was to test the acute influence of a ten-day altitude training camp (1850 m ASL) on changes in performance (AP, ANP, CI) in welltrained adolescents on cross-country skis.

Changes in performance were tested at various phases of the acclimatisation process for the intensities AP, ANP and CI using a field cross-country ski test measuring heart rate (HR) values and lactate and changes in speed. The results attained at altitude were compared to each other and with the initial low altitude test conducted immediately before departure and the test ten days after the return from high altitude.

\section{Methods}

\section{Participants}

All participants were youth Nordic skiers $(N=11$, age: $14.4 \pm 1.2$ years) and members of the Ski club Vimperk, Czech Republic (Table 1). All participants regularly take part in the Czech Cup in cross-country skiing and have been regularly trained for $4.3 \pm 1.9$ years on average. The skiers were in good health during the research period and under regular medical supervision during the whole training year. Considering the fact that the research took place during the beginning of the training period, the training process in the microcycle prior to the inaugural testing focused on aerobic training with high volumes and low intensity load, which took 12 hours in 7 training units. During the training camp at altitude (1850 m ASL, Livigno, Italy), competitors practiced 12 to 17 hours in nine training and two rest days. In light of the low age of the participants, only some of them underwent laboratory stress tests, 
based on which individual AP, ANP and CI values were individually determined. For the participants who did not undergo this testing, the intensities were determined by experts in collaboration with their coach.

Table 1

Basic anthropometric characteristics of participants

\begin{tabular}{lrrrc}
\hline & $\begin{array}{r}\text { Fat } \\
(\%)\end{array}$ & $\begin{array}{c}\text { Weight } \\
(\mathrm{kg})\end{array}$ & $\begin{array}{c}\text { Height } \\
(\mathrm{cm})\end{array}$ & $\begin{array}{c}\text { BMI } \\
\left(\mathrm{kg} \cdot \mathrm{m}^{-2}\right)\end{array}$ \\
\hline Mean & 13.1 & 54.4 & 170 & 19.5 \\
Standard deviation & 3.8 & 10.5 & 11 & 1.9 \\
Average deviation & 2.6 & 8.6 & 7 & 1.4 \\
\hline
\end{tabular}

\section{Instrumentation, protocol}

A modified terrain test (Suchý, 2012) was used: $3 \times 2 \mathrm{~km}$ (aerobic, anaerobic and critical intensity) with a 10 minute rest interval (for the test schema see Table 2). The intensities were individually defined by incremental exertion test (Bunc, 1990) and expert view. Overall the participants performed four batteries of tests:

1. 11 July 2013 - immediately before departure for altitude (Vimperk, Czech Republic, 900 m ASL)

2. 16 July $2013-3^{\text {rd }}$ day after arriving at altitude (Livigno, Italy, $1835 \mathrm{~m} \mathrm{ASL)}$

3. 20 July $2013-8^{\text {th }}$ day after arrival (Livigno, $1835 \mathrm{~m}$ ASL)

4. 29 July 2013 - nine days after return from altitude (Vimperk, $900 \mathrm{~m}$ ASL)

All four tests were realized on a $500 \mathrm{~m}$ stretch of flat asphalt. At the starting line and turnaround $(500 \mathrm{~m})$ members of the realisation team control the participants. Participants checked their HR values individually on heart rate monitors, where an informational sound signal was set at an interval \pm 5 from the established intensity.

The HR values were always the same for the respective intensity (AP, ANP, CI) in each section. Changes in actual performance and high and low altitude were determined on the basis of the differences in times achieved in the different segments.

To determine the internal response of the body to the load, lactate was also taken from the capillary blood immediately following the exertion and at the $8^{\text {th }}$ minute following the given segment (after CI at the second minute as well). The blood samples were analysed using a SenzoStar GL (Dr Müller Gerätebau, Freital, Germany) with a measurement variation coefficient of $<2.5 \%$ over 24 samples.

In determining the basic anthropomorphic data a non-standardised questioning was also performed focused on a basic social anamnesis, feelings from the training and time spent at altitude.

\section{Data analysis}

The consistency or statistical significance of the difference in the mean values of the times achieved, HR and lactate concentration was determined with a paired t-test for two independent selections. In accordance with similar studies (e. g. Bonetti \& Hopkins, 2009) we used the cut-off of $p<.05$ for statistical significance. Microsoft Excel (Version 2010; Microsoft, Redmond, WA, USA) was used for subsequent processing and analysis.

The study design complies with the Helsinki Declaration and was approved by the Ethics Committee of the Charles University, Faculty of Physical Education and Sport on 5 June 2013. The parents of all underage

Table 2

Course of the testing

\begin{tabular}{|c|c|}
\hline Minutes & Activity \\
\hline-15 to $-0.5 \mathrm{~min}$ & warm-up \\
\hline$-0.5 \min$ & lactate measurement \\
\hline $0 \mathrm{~min}$ & start of $2 \mathrm{~km}$ run at aerobic threshold \\
\hline 8 to $10 \mathrm{~min}$ & $\begin{array}{l}\text { completion of the first test (according to individual performance) } \\
\text { lactate measurement (immediately after the test) active rest for whole period - walking } \\
\text { lactate measurement } 2 \text { min after completion of the test }\end{array}$ \\
\hline 18 to $20 \mathrm{~min}$ & $\begin{array}{l}\text { (10 min after completion of the first test) start of } 2 \mathrm{~km} \text { run at anaerobic threshold } \\
\text { lactate measurement (immediately after the test) active rest for whole period - walking } \\
\text { lactate measurement } 2 \mathrm{~min} \text { after completion of test }\end{array}$ \\
\hline 35 to $43 \mathrm{~min}$ & $\begin{array}{l}\text { (10 min after completion of the second test) start of } 2 \mathrm{~km} \text { run at critical intensity } \\
\text { lactate measurement (immediately after the test) active rest for whole period - walking } \\
\text { lactate measurement } 2 \text { min after completion of the test }\end{array}$ \\
\hline 50 to $70 \mathrm{~min}$ & (according to individual performance) individual jogging and stretching \\
\hline
\end{tabular}


participants signed an informed consent form prior to testing. The authors have no conflict of interest in connection with this study.

\section{Results}

The testing took place in accordance with the established methodology. The participants reached the set load intensities for the individual tests on average after $30 \mathrm{~s}$ for AP, $45 \mathrm{~s}$ for ANP and $60 \mathrm{~s}$ at CI.

The average times achieved at AP and ANP intensity defined at normal altitude listed in Table 3 and 4 show that on the third day of altitude the participants achieved significantly $(p<.05)$ higher mean times than at the initial control test at low altitude. Following the return to low altitude they achieved higher times than in first tests, but there was no significant improvement with the second altitude test.

The average times achieved at critical intensity at the same HR nine days after returning from the altitude training were significantly higher than at the initial testing. The average time results in the altitude tests confirm that on the third day of altitude the participants experienced a marked drop in performance in comparison with the entry test at low altitude.
The average lactate values listed in Table 5 correspond to the HR values customary for the age category. Changes in the average concentration of lactate immediately following the exertion were not significant, but this finding corresponds to the fact that the participants always observed the defined HR values. The changes in the average concentration of lactate over the course of the cool-down after the various intensities likewise failed to show significance.

The non-standardised questioning of the participants yielded the following responses:

- 8 interviewees fall asleep at altitude the same as in the lowlands, 3 wake up at night (primarily due to the dry air);

- 5 participants do not feel any significant changes in altitude training compared to low altitude; the others feel a markedly more rapid onset of fatigue and increased need for inspiration ("calves stiffen up", "more frequent cramps in sides", "harder to breathe", "dry throat");

- ten of the interviewees' fathers did sports, and eight of their mothers;

- a positive finding was that the majority of the interviewees' parents do not comment on the management of training but rather repeatedly declare their moral support for their children's sports activity.

Table 3

Summary of mean times achieved for individual tests at AP and ANP intensity with identical HR

\begin{tabular}{|c|c|c|c|c|c|c|c|c|}
\hline & \multicolumn{4}{|c|}{ Aerobic threshold (HR same as at lowland) } & \multicolumn{4}{|c|}{ Anaerobic threshold (HR same as at lowland) } \\
\hline & 11.7. & 16. 7. & 20.7. & 29.7. & 11. 7. & 16. 7. & 20.7 & 29.7. \\
\hline Mean & $15: 52$ & $14: 52$ & 13:00 & $12: 38$ & $10: 40$ & $10: 35$ & 9:57 & 9:50 \\
\hline Standard deviation & $1: 54$ & $1: 52$ & $1: 20$ & $1: 48$ & $1: 16$ & $1: 23$ & 1:09 & $1: 05$ \\
\hline Average deviation & $1: 34$ & $1: 31$ & $0: 59$ & $1: 33$ & 1:03 & 1:06 & $0: 57$ & $0: 52$ \\
\hline$t$-test 11. 7. vs. 16., 20., 29. 7. & & .016 & $<.001$ & $<.001$ & & .382 & $<.001$ & .005 \\
\hline$t$-test 16. 7. vs. 20., 29. 7. & & & $<.001$ & $<.001$ & & & $<.001$ & .001 \\
\hline$t$-test 20.7 . vs. 29.7 . & & & & .110 & & & & .274 \\
\hline
\end{tabular}

Table 4

Summary of times for individual tests at critical intensity with identical HR

\begin{tabular}{llccc}
\hline & \multicolumn{4}{c}{ Critical intensity (HR same as at lowland) } \\
\cline { 2 - 5 } & 11.7. & 16.7. & 20.7. & 29.7. \\
\hline Mean & $9: 00$ & $9: 16$ & $9: 07$ & $8: 32$ \\
Standard deviation & $1: 08$ & $1: 05$ & $1: 01$ & $0: 55$ \\
Average deviation & $0: 50$ & $0: 48$ & $0: 43$ & $0: 42$ \\
$t$-test 11. 7. vs. 16., 20., 29. 7. & & .149 & .192 & .010 \\
$t$-test 16. 7. vs. 20., 29. 7. & & & .004 & .012 \\
$t$-test 20. 7. vs. 29. 7. & & & & .032 \\
\hline
\end{tabular}




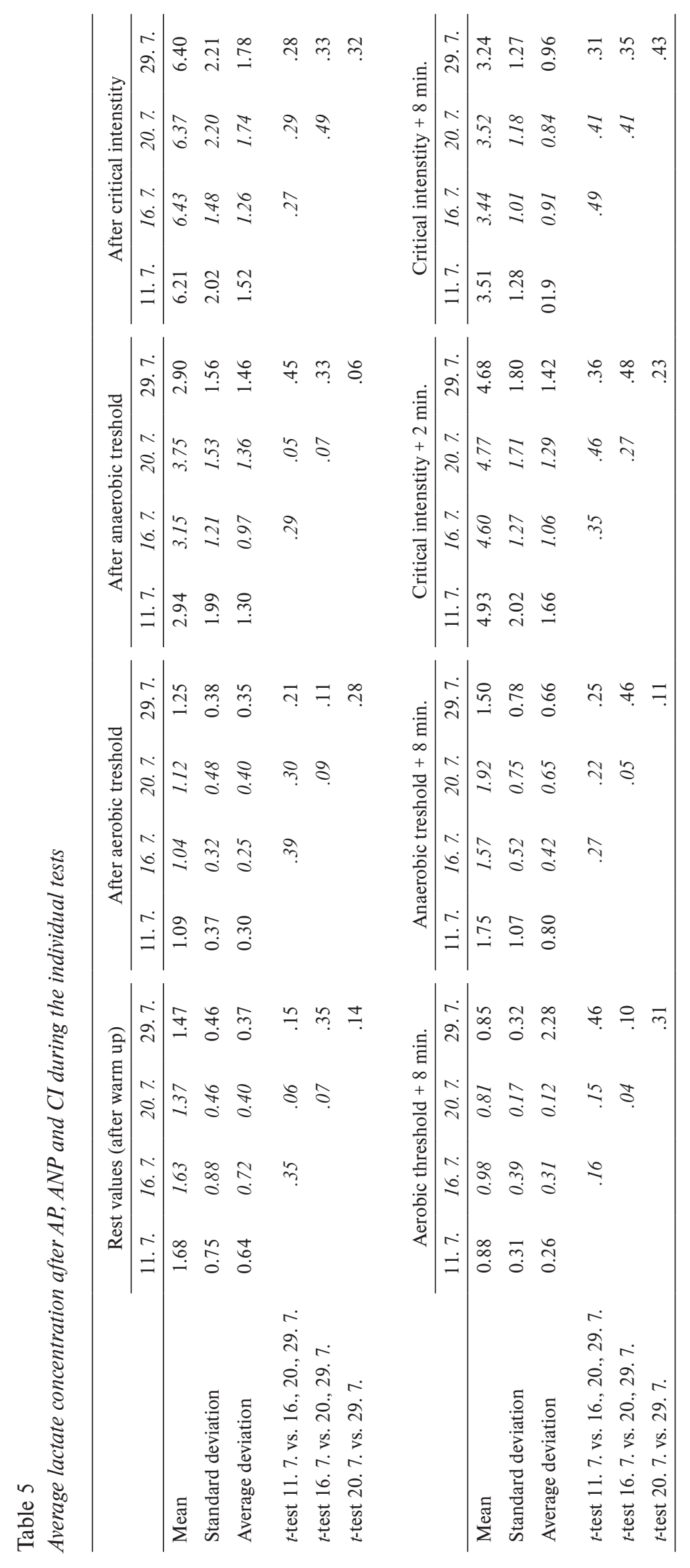




\section{Discussion}

The positive effect of higher altitudes on the current performance level at all three monitored intensities following a return from the ten-day altitude training to lower altitudes demonstrated by our measurements of the adolescents corresponds to the results of studies performed on adults (e.g. Suchý, 2012; Suchý, Pernica, \& Opočenský, 2014; Wilber, 2004). Likewise the expected lower speed at CI found in both non-standardised tests at altitude compared to low altitude was in keeping with previously published studies.

A comparison of the average times from both altitude tests shows that the adolescents had the worst performance on the third to fifth day of altitude with subsequent improvement. These findings correspond to those published on the course of the acclimatisation process in adults (Suchý, 2012; Suchý, Pernica, \& Opočenský, 2014). The classic studies of Buskirk, Kollias, Akers, Prokop, and Reategui (1967) or Daniels and Oldridge (1970) state a drop in performance for very good adult endurance athletes in a test for 1 mile at an altitude of $2200 \mathrm{~m}$ ASL on the first ten days of altitude ranging from 8 to $15 \%$. Wilber (2004) summarises the results of newer studies on the issue in adults: "The drop in aerobic performance in top endurance athletes in the first days at altitude ranges between 2 and $28 \%$ and $\mathrm{VO}_{2}$ max falls 14 to $29 \%$ in comparison with lowland data".

The results in our study correspond to the improvement of performance in adolescents following return from a three week training session at high altitude published by Christoulas (1999), Christoulas, Karamouzis, and Mandroukas (2011), and Son et al. (2012).

The insufficient experience of the participants with this type of testing however unfortunately resulted in skewed data from the initial test for AP and ANP. For this reason it would have improved the relevance of the results to repeat the control test in the lowlands, but this was unfortunately impossible due to time constraints. In our opinion, CI was not influenced at the initial test so much like on the AP and ANP loads.

Lactate testing after warm-up was conducted above all in order to determine whether any of the participants have a high resting concentration (more than $2.5 \mathrm{mmol} \cdot \mathrm{1}^{-1}$ in the blood) that might indicate overexertion. None of the participants had a high at-rest lactate value, so no one needed to be disqualified from the testing. For the reasons mentioned above it was also not possible to compare the lactate concentration at the initial test following AP and ANP intensity. The average lactate values measured show that only HR can be used for training management if necessary, though naturally only if no limit load is applied (volume or intensity). The fact that no significant changes in lactate were determined during testing at altitude and at low altitude goes against, for example, the classic study Peronnet, Thibault, and Cousineau (1991) conducted on adults; this fact could thus be a result of the low age of the participants in our study.

With regard to the methodology of testing the stated load intensity (aerobic, anaerobic and critical), for some participants, particularly in the lowland tests, did not corresponded to the definition stated in the theoretical part of the article, but for the sake of clarity we did not consider it appropriate to use other terms.

When preparing the study we considered whether or not to use a more specific test on roller skis, but for safety and technical reasons running was chosen in the end. We also considered monitoring intersexual changes in performance, but in light of the low number of participants and the scope of the article this breakdown was not made. Assessing the design of the study in retrospect we believe that it would be interesting to use the Borg Scale to evaluate exertion (e.g. Čechovská $\&$ Dobrý, 2008). The reason for this is the subjective observation of the realisation team, to whom it seemed that the exertion in the second test at low altitude evoked a markedly lesser response than the first one. Groslambert, Bendit, Grange, and Rouillon (2005) state that the Borg Scale is appropriate for the age of our participants.

Aside from the above findings the present study also encountered the following limits:

- participants had insufficient or complete lack of experience with altitude training;

- with regard to the low age of the participants, some had little experience with the use of heart rate monitors and this type of testing;

- there were difficulties measuring HR on very thin participants;

- possible insufficient prior training load;

- regard to the low age of the participants the measured values of lactate in the capillary blood may not correspond to the values for similar exertion customary in adults;

- as a result of the individual warm-up it was not possible to evaluate the initial lactate level;

- a theoretical possibility for how to increase the predictive value of our investigation was to conduct it on a greater number of athletes using a control group that would undertake the same load at low altitude. We considered this fact when planning the design of the study, but due to socioeconomic and 
organisational aspects we were unfortunately unable to procure a larger sample of participants. A metaanalysis of studies published on the issue of training at high altitudes (Bonetti \& Hopkins, 2009) also shows that similarly small number of persons (most frequently 5 to 15 ) are used for this type of investigation, generally without control groups, as was the case in our study.

The positives of the study primarily include:

- the enormous motivation of the participants in testing, which was evident in all four tests;

- the finding that the course of acclimatisation processes at higher altitudes is similar in adolescents to that of adults.

Despite the positive results we found, we believe that regular inclusion of altitude training camps for adolescents is superfluous. It is appropriate to use shorter stays at higher altitudes essentially as a mere motivational element, not as a regular methodological component for developing performance. Even without support in relevant longitudinal studies we believe that otherwise it is not possible then to use higher altitudes in adulthood as a strong impulse to further increase performance. Our participants were also in Livigno as a reward and to increase their motivation for training.

\section{Conclusions}

In the model we were testing, the ten day altitude training camp (1850 m ASL) for the tested adolescents had a significant positive effect on acute improvement of their performance ten days after returning to low altitude. The course of the acclimatisation process was similar in the monitored adolescents to that in adults, because on the third day at altitude they achieved statistically significantly worse results than on the eighth day.

As with adults (Suchý, 2012; Wilber, 2004), it is physiologically suitable for adolescents to include altitude stays and training with the objective of a subsequent rise in performance at low altitude.

\section{Acknowledgment}

This research was supported by The Ministry of Education, Youth and Sports Czech Republic (MSM 0021620864), the program for the development of scientific disciplines at Charles University PRVOUK P38.

\section{References}

Bonetti, D. L., \& Hopkins, W.G. (2009). Meta-analysis of sea level performance following adaptation to hypoxia. Sports Medicine, 39, 107-127.

Bunc, V. (1990). Biokybernetický prístup $k$ hodnocení reakce organismu na tělesné zatižení [Biocybernetical approach to evaluating the response of the organism to physical exercise]. Praha: Univerzita Karlova.

Buskirk, E. R., Kollias, J., Akers, R. F., Prokop, E. K., \& Reategui, E. P. (1967). Maximal performance at altitude and on return from altitude in conditioned runners. Journal of Applied Physiology, 23, 259-266.

Christoulas, K. (1999). Effects of altitude sojourn and training on performance of adolescent female cross-country skiers. Medical Science Research, 27, 13-16.

Christoulas, K., Karamouzis, M., \& Mandroukas, K. (2011). "Living high - training low" vs. "living high - training high": Erythropoietic responses and performance of adolescent cross-country skiers. Journal of Sports Medicine and Physical Fitness, 51, 74-81.

Čechovská, I., \& Dobrý, L. (2008). Borgova škála subjektivně vnímané námahy a její využití [Borg's scale of subjectively perceived exercise and its use in practice]. Tělesná výchova a sport mládeže, 74(3), 37-45.

Daniels, J., \& Oldridge, N. (1970). The effects of alternate exposure to altitude and sea level on world-class middle-distance runners. Medicine and Science in Sports, 2, 107-112.

Groslambert, A., Bendit, P. M., Grange, C. C., \& Rouillon, J. D. (2005). Selfregulated running using perceived exertion in children. Journal of Sports Medicine and Physical Fitness, $45,20-25$.

Heinecke, K., Heinicke, I., Schmidt, W., \& Wolfarth, B. (2005). A three week traditional altitude training increases hemoglobin mass and red cell volume in elite biathlon athletes. International Journal of Sports Medicine, 26, 350-355.

Keul, J. Kindermann, W., \& Simon, G. (1978). Die aerobe und anaerobe Kapazität als Grundlage für die Leistungsdiagnostik [The aerobic and anaerobic capacity as a basis for performance diagnostics]. Leistungssport, 1, 22-32.

Levine, B. D., \& Stray-Gundersen, J. (1997). "Living high - training low": Effect of moderate-altitude acclimatization with low-altitude training on performance. Journal of Applied Physiology, 83, 102-112.

Millet, G., \& Schmitt, L. (2001). S'entraîner en altitude, mécanismes, méthodes, exemples, conseils pratiques [Training at altitude, mechanisms, methods, examples, practical advice]. Brussel: De Boeck.

Neumann, G., Pfützner, A., \& Berbalk, S. (1998). Optimiertes Ausdauertraining [Optimized endurance training]. Aachen: Meyer \& Meyer Verlag.

Pahud, F. (1986). Training at altitude: General principles and personal experience. New Studies in Athletics, 3, 53-57.

Peronnet, F., Thibault, G., \& Cousineau, D. L. (1991). A theoretical analysis of the effect of altitude on running performance. Journal of Applied Physiology, 70, 399-491.

Pollard, A. J., Durmowicz, A., Durrer, B., Eldridge, M., Hackett, P., Jean, D., ... Dietz, T. E. (2001). Children at high altitude: An international consensus statement by an ad hoc committee of the international society for mountain 
medicine, March 12, 2001. High Altitude Medicine and Biology, 2, 389-403.

Saunders, P. U., Pyne, D. B., \& Gore, C. J. (2009). Endurance training at altitude. High Altitude \& Biology, 10, 135-148.

Son, H. J., Kim, H. J., Kim, J. H., Ohno, H., \& Kim, C. K (2012). Erythropoietin, 2,3 DPG oxygen transport capacity, and altitude training in adolescent skier. Aviation, Space, and Environmental Medicine, 83, 50-53.

Suchý, J. (2012). Využití hypoxie a hyperoxie ve sportovním tréninku [Use of hypoxia and hyperoxia in sports training]. Praha: Karolinum.

Suchý, J., \& Dovalil, J. (2009). Problematika tréninku ve vyšší nadmořské výšce $\mathrm{z}$ pohledu trenérů [The issue of high altitude training from the perspective of trainers]. Telesná výchova \& šport, 18(3-4), 4-8.
Suchý, J., Pernica, J., \& Opočenský, J. (2014). Změny sportovní výkonnosti ve vyšši nadmořské výšce u běžců na lyžich [Changes of sports performance at high altitude in cross-country skiers]. Studia Sportiva, 8(1), 101-108.

Svedenhag, J., Saltin, B., Johansson, C., \& Kaijser, L. (1991). Aerobic and anaerobic exercise capacities of elite middledistance runners after two weeks of training at moderate altitude. Scandinavian Journal of Medicine Science in Sports, 1, 205-214.

Wilber, L. R. (2004). Altitude training and athletic performance. Champaign, IL: Human Kinetics.

Wilmore, J., Costill, D., \& Kenney, W. (2008). Physiology of sport and exercise. Champaign, IL: Human Kinetics. 